\title{
以德树人改革创新,努力创建现代化学校
}

\author{
周守太 \\ 山东省淄博市沂源县实验中学 \\ D O I:10.32629/jief.v2i1.484
}

[摘 要] 近年来, 山东省沂源县实验中学以“立心立人”作为办学核心理念, 坚持走内涵性特色发展之路, 努力创建现代化学校,顺利完成 了教育教学工作目标及重点工作。2019学年学校获得了省级文明校园、淄博市中小学德育工作先进单位、淄博市教育系统模范教工之家、淄 博市先进基层党组织、淄博市教育系统党建示范点、沂源县优秀家长学校、沂源县中华优秀传统文化教育示范校等荣誉称号。

[关键词]以德树人；改革创新；现代化

\section{1 优化校园智慧化工程, 提升学校办学条件}

近年来, 学校围绕三年发展规划, 按照学校工作整体部署, 加强信 息技术与教学融合, 抓好教师项目的训练与比赛, 促进学科与信息技术的 深度融合, 创新开展信息化教学教研, 分步推进智慧校园建设。学校以义 务教育优质均衡发展县创建为契机, 投资几百万元, 新配电脑 200 多台, 实现了老师所有微机的升级换代; 新建了录播室、网络同步课堂, 配备了 48 台触控一体机; 完成了对报告厅舞台的设计改造, 完成了舞台灯光、 电子屏、音响、地面改造; 完成了党员活动室、心理咨询室的改造的施工 工作, 大大提升了学校的办学条件。

学校利用全智能录播室和无线网络搭建了录课、观课、评课的智慧 教研平台, 教师的专业素养得到提升; 以学科科研为立足点, 突破薄弱学 生, 借助互联网+打造智慧教育的新课堂, 组建了电子书包班, 探索线上 与线下相结合的学习模式, 探索学科教学与信息技术深度融合, 提高课堂 教学效率, 设备使用率达到较高水平; 学校征订了 180 多种教育教学报刊 杂志, 馆配图书达 11 万册, 完全满足了教师学习及教科研的需求; 学校 定期向师生开放图书阅览室, 开拓了师生视野。

2 实施干部优良化工程, 创新学校管理模式

学校以建章设制为统领, 修改完善《学校章程》, 构建新型的学校干 部管理组织体系。学校深入实施干部优良化工程, 形成了科学化、民主化、 规范化、法治化、人本化的干部制度体系, 培养了一批政治素质好, 奉献 精神强, 管理能力高, 有创新精神的一流干部队伍。

学校实行中层干部竞聘上岗制, 实行 “1335 管理运行机制”, 建立了 科学、民主、高效的扁平化管理机制, 让学校管理更加透明、更加高效; 完善干部考核评价制度, 制定了管办评分离的评价条例; 完善奖惩激励机 制。学校开展 “半天无课日”、每周教师读书荐读以及外出培训、举办青 年教师讲课比赛等活动, 提升了教师的教育教学水平。学校在每年教师节 前夕, 都选树并宣传了一批优秀干部、教师, 通过评选振华园丁奖、“优 秀教师” “优秀班主任” 等活动, 树立标杆, 表扬先进, 充分发挥了典型 的示范引领作用。

3 实施德育一体化工程，提高学校德育水平

学校每年都在教师节、中秋节、国庆节、国家公祭日举行了系列活 动, 在活动中教育学生感恩、孝亲、爱国等优秀品德。建立了优秀班主任 培训机制, 针对新上岗班主任比较多的情况, 各级部开展了一对一结对帮 扶活动, 力争新班主任尽快成长。落实学校制定的 “新三好” (读好书、 写好字、做好人）培养制度，以文明校园创建为契机；制定了 “六好” (走 好路、穿好衣、上好课、做好操、吃好饭、睡好觉) 实施方案, 进一步巩 固文明校园创建成果, 提高了学生的文明水平。

学校成立了红枫艺术社团, 设立经典诵读社、合唱团、民乐团、舞 蹈社、美术、课本剧、书法、绘画、团体操、足球、篮球等 19 个社团; 2019 年社团新增了无人机、机器人等创客社团, 陶笛社团、动漫绘画社 团、诗词鉴赏社团。学校充分利用了学校现有的各功能用室, 包括史地教 室、阅览室、实验室、音乐教室、学生教室、合唱教室、操场、舞蹈、器
乐、书法、绘画教室, 还充分利用了周边场地资源, 如青少年活动中心。 聘任了陈大鲁、解明全 2 名老年大学志愿老师和 8 名校外专业志愿辅导教 师, 举行了聘任仪式, 颁发了聘书。初一、初二 1500 余名学生参加社团 活动, 受到师生、家长的好评, 全县现场会也在我校召开。社团活动让每 一个学生都有成长的舞台, 让每一个学生都能享受到成功的喜悦, 享有更 大的发展空间。

4 创新教师队伍建设, 推进教师专业化发展

近年来, 学校采取了 “走出去、请进来” 的方式, 组织骨干教师、 教研组长、备课组长到青岛开发区实验学校等省内外名校参观学习, 与全 国名校洋思中学课堂教学进行深度对接; 县内与西里中学结成教育共同体 学校, 发挥学校的示范带头作用; 和重庆石柱县沙子中学结对帮扶, 先后 派出十几名教师进行交流学习。

学校大力推广 “自主互助、有效合一” 六环节课堂教学模式, 深入 开展教师 “四课” 活动, 即新上岗教师汇报课、骨干教师观摩示范课、青 年教师展示课、课堂创新达标课课等活动; 开展 “立标、学标、达标” 及 “青蓝工程” 活动, 不断提升教师教育教学及业务水平; 抓实教师分层次 培养工作, 定期开展教师业务培训, 加快青年教师成长步伐, 促进骨干教 师向名师的转化, 全面构建新教师、青年教师、骨干教师、优秀教师、名 师以及教育管理干部内容丰富、形式多样的培养培训机制, 永葆教师队伍 的动力和活力。

\section{5 弘扬优良师德师风，加强师德师风建设}

学校组织开展 “师德教育学习周” “师德建设教育月” 和 “教师向学 生和家长公开承诺践诺” 活动, 切实增强教师依法执教、文明执教意识和 能力, 自觉践行办学行为规范。严格贯彻执行《中小学教师职业道德规范》 《中小学教师违反职业道德行为处理办法》《山东省普通中小学违规办学行 为责任追究暂行办法》《畄博市中小学教师职业道德行为规范细则》以及 “淄博市教师十不准” 等规定, 强化师德教育活动。

展望未来, 学校将继续坚持 “提质增效” 总基调, 依托自身优势, 围绕 “立心立人” 办学理念, 围绕 “打造优质团队、培育优秀人才、创建 品牌学校” 的奋斗目标, 深入实施三年发展规划七大工程, 在 2020 年将 继续发挥移山填海的拼搏进取精神, 机遇在手, 蓝图在胸, 同心协力, 实 现学校教育管理的跨越发展。

[参考文献]

[1] 龙成银. 以德树人更需 “红色引擎” 驱动 [ J]. 人民论 坛,2019(16):104- 105.

[2] 黄雪, 武或. 以史育人, 以德树人, 绽放化学课堂精彩 [J].广州化 工,2019,47(06):148 150.

[3] 黎志强. 坚持以德树人以美育人以文化人 [ J]. 甘肃教 育, 2018(20):8-9.

作者简介: 周守太 (1965) , 男, 汉族, 山东沂源人, 本科, 中 学高级教师, 研究方向: 学校管理创新与实践探索, 现为沂源县实验 中学校长。 